\title{
Marinobacter sp. from marine sediments produce highly stable surface-active agents for combatting marine oil spills
}

\author{
Noura Raddadi* (D), Lucia Giacomucci, Grazia Totaro and Fabio Fava
}

\begin{abstract}
Background: The application of chemical dispersants as a response to marine oil spills is raising concerns related to their potential toxicity also towards microbes involved in oil biodegradation. Hence, oil spills occurring under marine environments necessitate the application of biodispersants that are highly active, stable and effective under marine environment context. Biosurfactants from marine bacteria could be good candidates for the development of biodispersant formulations effective in marine environment. This study aimed at establishing a collection of marine bacteria able to produce surface-active compounds and evaluating the activity and stability of the produced compounds under conditions mimicking those found under marine environment context.

Results: A total of 43 different isolates were obtained from harbor sediments. Twenty-six of them produced mainly bioemulsifiers when glucose was used as carbon source and 16 were biosurfactant/bioemulsifiers producers after growth in the presence of soybean oil. Sequencing of 165 rRNA gene classified most isolates into the genus Marinobacter. The produced emulsions were shown to be stable up to 30 months monitoring period, in the presence of $300 \mathrm{~g} / \mathrm{I} \mathrm{NaCl}$, at $4{ }^{\circ} \mathrm{C}$ and after high temperature treatment $\left(120^{\circ} \mathrm{C}\right.$ for $\left.20 \mathrm{~min}\right)$. The partially purified compounds obtained after growth on soybean oil-based media exhibited low toxicity towards V. fischeri and high capability to disperse crude oil on synthetic marine water.

Conclusions: To the best of our knowledge, stability characterization of bioemulsifiers/biosurfactants from the non-pathogenic marine bacterium Marinobacter has not been previously reported. The produced compounds were shown to have potential for different applications including the environmental sector. Indeed, their high stability in the presence of high salt concentration and low temperature, conditions characterizing the marine environment, the capability to disperse crude oil and the low ecotoxicity makes them interesting for the development of biodispersants to be used in combatting marine oil spills.
\end{abstract}

Keywords: Surface-active compounds, Marinobacter sp., Marine oil spills bioremediation, Biodispersants, Stability

\section{Introduction}

Biosurfactants (BS) are amphipathic compounds produced by a variety of microorganisms. These compounds could be of low-molecular weight type, which are generally glycolipids and lipopeptides, and high-molecular weight type which are mainly lipopolysaccharides, lipoproteins or a combination of both. The high-molecular weight biosurfactants, frequently called bioemulsifiers

*Correspondence: noura.raddadi@unibo.it

Department of Civil, Chemical, Environmental and Materials Engineering

(DICAM), Alma Mater Studiorum-University of Bologna, Bologna, Italy
(BE), are associated with production of stable emulsions, but do not always exhibit lowering of the surface or interfacial tension [1, 2]. The broad range of applications of these compounds has been documented by several patents on their use. Specifically, in 2006, 250 patents have been deposited worldwide and were mainly related to the use of BE/BS in petroleum (33\%) or cosmetic (15\%) industries; in medicine (12\%) and in bioremediation (11\%) [3]. Specifically, in bioremediation processes they play a crucial role in enhancing the bioavailability of hydrophobic compounds like hydrocarbons. Nonetheless, their 
application in response to oil spills in marine environment is not a common practice and chemical dispersants are currently the only products used [4]. The application of chemical dispersants is rising, however, some concerns due to their toxicity and negative effects on the activity of natural oil-degrading microorganisms [4]. Therefore, microbial surfactants, owing to their biodegradability and low toxicity $[2,5,6]$, could be an alternative to their chemical counterparts for the development of biodispersants. The marine environment including oceans or oil reservoirs are characterized by high salinity reaching more than $150 \mathrm{~g} / \mathrm{l}$ of $\mathrm{NaCl}$ [7] and quite low temperature that can range between 1 and $10^{\circ} \mathrm{C}[8,9]$. Given the need for surface-active compounds with potential application for bioremediation under marine environmental conditions, interest in the selection of biosurfactants-producing marine microbes has been increasing. Microbes from marine habitats represent indeed an excellent opportunity to discover novel biosurfactants that are likely to function in marine ecosystems characterized by temperature extremes and low water activity $[10,11]$.

In this work, we aimed to (1) establish a collection of marine bacteria able to produce surface-active compounds after growth on soybean oil and/or glucose-based media and (2) characterize the produced compounds in terms of activity and stability also under challenging conditions.

\section{Methods}

\section{Bacterial isolation}

Marine sediment samples were collected from three Mediterranean harbors in the south of Italy in October 2013. Bacterial isolation was performed by spreading serial dilutions of grinded sediment samples in sterile saline solution $(30 \mathrm{~g} / \mathrm{l} \mathrm{NaCl}$ in distilled water) on agar plates of modified mineral salt medium (mMSM) containing $1 \%_{\mathrm{w} / \mathrm{v}}$ of glucose as the major carbon source. The mMSM has the following composition (g/l): $\mathrm{Na}_{2} \mathrm{HPO}_{4}, 0.7 ; \mathrm{KH}_{2} \mathrm{PO}_{4}, 0.9 ; \mathrm{NaNO}_{3}, 2 ; \mathrm{MgSO}_{4} \cdot 7 \mathrm{H}_{2} \mathrm{O}$, $0.4 ; \mathrm{CaCl}_{2} \cdot 2 \mathrm{H}_{2} \mathrm{O}, 0.1 ; \mathrm{NaCl}, 30$ and $2 \mathrm{ml}$ of trace element solution (per liter, $2 \mathrm{~g} \mathrm{FeSO}_{4} \cdot 7 \mathrm{H}_{2} \mathrm{O}, 1.5 \mathrm{~g} \mathrm{MnSO}_{4} \cdot \mathrm{H}_{2} \mathrm{O}$, $\left.0.6 \mathrm{~g}\left(\mathrm{NH}_{4}\right)_{6} \mathrm{Mo}_{7} \mathrm{O}_{24} \cdot 4 \mathrm{H}_{2} \mathrm{O}\right)$. The $\mathrm{pH}$ of the medium was adjusted to 7.0 before autoclaving and solid medium was prepared by adding $15 \mathrm{~g} / \mathrm{l}$ of agar.

\section{Screening for biosurfactant/bioemusifier production}

Pure isolated strains, obtained by three successive streakings on mMSM agar plates, were inoculated into mMSM broth with $1 \%_{\mathrm{w} / \mathrm{v}}$ of glucose or $2 \%_{\mathrm{v} / \mathrm{v}}$ of soybean oil as carbon source and the flasks were incubated at 30 or $20^{\circ} \mathrm{C}$ on a rotary shaker $(150 \mathrm{rpm})$. After bacterial growth, the cell-free culture supernatants were recovered by centrifugation $\left(10,000 \mathrm{rpm}, 10 \mathrm{~min}, 4{ }^{\circ} \mathrm{C}\right)$, filter-sterilized
$(0.22 \mu \mathrm{m})$ and subjected to $\mathrm{BS} / \mathrm{BE}$ production screening using three methods. Solutions of $0.5 \%_{\mathrm{w} / \mathrm{v}}$ of sodium dodecyl sulphate (SDS) and Tween 80 were used as positive controls; while deionized water and noninoculated growth medium as negative controls.

Emulsification activity (EA) was determined as described by [12] using $2 \mathrm{ml}$ of culture supernatant and $2 \mathrm{ml}$ of the tested organic solvent ( $n$-hexane, toluene). The emulsification index value was recorded after $24 \mathrm{~h}$ $\left(\mathrm{EI}_{24}\right)$ and expressed as the percentage of the height of the emulsion layer to the total height.

All screening assays were performed in triplicate as independent experiments.

Drop collapse The test was carried out as follows: $40 \mu \mathrm{l}$ of the cell free supernatant was aliquoted as a droplet onto Parafilm ${ }^{\circledR}$ (Parafilm M, Germany) surface; the flattening and the spreading of the droplet was followed over $10 \mathrm{~min}$ and recorded by visual inspection. If the drop remained beaded, the assay was scored negative, and if the drop collapsed, the result was positive.

Interfacial surface tension (IFT) of the cell-free culture supernatant was measured with a Drop Shape Analyzer-DSA30 (KRUSS GmbH, Germany) working in the pendant drop mode. The surface tension was calculated from at least three measurements by the instrument software using the Young-Laplace method. Deionized water and sterile medium were used as references for high IFT liquids, while SDS as low IFT reference.

\section{Stability of bioemulsifiers}

Stability studies were performed using cell-free culture supernatants. In order to assess the effect of salinity on the bioemulsifier activity, culture supernatants were supplemented with $\mathrm{NaCl}$ up to a final concentration of $300 \mathrm{~g} / \mathrm{l}$ and the emulsifying activity was measured as described above. To evaluate the stability of the bioemulsifier at high temperatures, culture supernatants were subjected to autoclaving $\left(121^{\circ} \mathrm{C}\right.$ for $\left.20 \mathrm{~min}\right)$; the samples were then cooled to room temperature and the emulsification indexes $\left(\mathrm{EI}_{24}\right)$ were measured and compared to the corresponding values before treatment. The activity and stability of the bioemulsifiers was evaluated at $4{ }^{\circ} \mathrm{C}$ using culture supernatants and solvents that were cooled to $4{ }^{\circ} \mathrm{C}$ and incubated at $4{ }^{\circ} \mathrm{C}$ after vortexing. Furthermore, the stability of the emulsions produced was monitored for up to 30 months after incubation at room temperature or $4{ }^{\circ} \mathrm{C}$. All the experiments were carried out in triplicate. The results were reported as residual emulsification activity (REA) (\%) expressed as follows:

$$
R E A(\%)=\frac{E I_{t}}{E I_{24}} \times 100
$$


where $E I_{t}$ is the EI (\%) value at time $t$; and compared with the positive controls.

\section{Partial purification of biosurfactants/bioemulsifiers}

After growth in mMSM supplemented with $2 \%_{\mathrm{w} / \mathrm{v}}$ soybean oil, culture supernatants were recovered by centrifugation $\left(10,000 \mathrm{rpm}, 10 \mathrm{~min}, 4^{\circ} \mathrm{C}\right)$, filter-sterilized $(0.22 \mu \mathrm{m}$ filter $)$, acidified with $6 \mathrm{~N}$ hydrochloric acid solution to $\mathrm{pH} 2.0$ and allowed to settle at $4{ }^{\circ} \mathrm{C}$ overnight. The precipitated crude $\mathrm{BE} / \mathrm{BS}$ collected by centrifugation $(10,000 \mathrm{rpm}$, $\left.20 \mathrm{~min}, 4{ }^{\circ} \mathrm{C}\right)$ were dried $\left(4-5 \mathrm{~h}\right.$ at $\left.50{ }^{\circ} \mathrm{C}\right)$ and either used for FT-IR analysis or dissolved in distilled $\mathrm{H}_{2} \mathrm{O}$ and adjusted to $\mathrm{pH} 7.0$ using $1 \mathrm{~N} \mathrm{NaOH}$ for $\mathrm{CMCs}$ determination. The dissolved BE/BS were also subjected to dialysis (cut-off 14,000 Da, Sigma-Aldrich Co.) before using for ecotoxicological analysis or oil displacement test.

\section{Preliminary chemical characterization of biosurfactants/ bioemulsifiers}

The infra-red spectra (FT-IR) of the dried BE/BS were recorded over the wavenumber range $450-4000 \mathrm{~cm}^{-1}$ using a Perking Elmer Spectrum One FT-IR spectrometer (transmission mode) after grinding with $\mathrm{KBr}$ to form a very fine powder (1/100 ratio) and compressing into a thin pellet. Thirty-two scans were taken for each spectrum at a resolution of $2 \mathrm{~cm}^{-1}$.

\section{CMC measurements}

Partially purified biosurfactants obtained by acid precipitation were dissolved in distilled $\mathrm{H}_{2} \mathrm{O}$ at $4 \mathrm{~g} / \mathrm{l}$ and then the solutions were diluted to concentration ranging from 0.10 to $3.7 \mathrm{~g} / \mathrm{l}$. The surface tension of each dilution was measured as described above. IFT values were plotted as a function of the logarithm of biosurfactant concentration and $\mathrm{CMC}$ was then calculated as the intersection point between the baseline of minimal surface tension and the slope where surface tension shows a linear decline.

\section{Evaluation of acute toxicity to the luminescent bacterium Vibrio fischeri}

Acute toxicity assays of partially purified $\mathrm{BE} / \mathrm{BS}$ were performed according to the standard protocol for the Microtox basic test [5] using $1 \mathrm{mg} / \mathrm{ml}$ for bioemulsifiers, or the specific CMC for biosurfactants. Results were reported as $\mathrm{EC}_{50}$, the effective concentration of partially purified biosurfactant that caused a $50 \%$ reduction in the amount of luminescence emitted by the bacterial suspension after $30 \mathrm{~min}$ of exposure.

\section{Dispersant assay}

The dispersant capacity of the BS/BE was evaluated by performing the oil displacement test carried out as follows: $20 \mu \mathrm{l}$ of light crude oil were slowly dropped onto the surface of $40 \mathrm{ml}$ of artificial seawater in a Petri dish $(9 \mathrm{~cm}$ in diameter) until covering the entire surface area of the water. Afterwards, $20 \mu \mathrm{l}$ of partially purified BS/BE solution prepared at the $\mathrm{CMC}$ concentration or at $1 \mathrm{~g} / \mathrm{l}$ were added onto the surface of the oil layer. The mean diameter of the clear zones was recorded from triplicate experiments. A solution of $1 \%_{\mathrm{w} / \mathrm{v}}$ SDS or distilled water were used as positive and negative controls, respectively.

\section{PCR amplification and sequencing of 16S rRNA gene}

PCR amplification of 16S rRNA gene was performed on DNA extracted from each isolate using the GenElute Bacterial Genomic Kit (Sigma) and bacterial universal primers 27f (5'-AGAGTTTGATCCTGGCTCAG-3') and 1492r (5'-CTACGGCTACCTTGTTACGA-3') with the following reaction conditions: $1 \times$ PCR buffer (Invitrogen, Milan, Italy), $1.5 \mathrm{mM} \mathrm{MgCl}, 0.2 \mathrm{mM}$ of each $\mathrm{dNTP}, 0.4 \mu \mathrm{M}$ of each primer, $1 \mathrm{U}$ of Taq polymerase in a final volume of $50 \mu \mathrm{l}$. Initial denaturation at $95{ }^{\circ} \mathrm{C}$ for 4 min was followed by 30 cycles consisting of denaturation at $95^{\circ} \mathrm{C}$ for $1 \mathrm{~min}$, annealing at $55^{\circ} \mathrm{C}$ for $1 \mathrm{~min}$, and extension at $72{ }^{\circ} \mathrm{C}$ for $2 \mathrm{~min}$. A final extension at $72{ }^{\circ} \mathrm{C}$ for $10 \mathrm{~min}$ was added. The amplification products were sequenced by the company Macrogen (South Korea). Sequences were checked for chimeras using DECIPHER software [13], identified using the BLASTn and a Neighbor-Joining phylogenetic tree was then built using MEGA6 [14], computing the evolutionary distances using the Jukes-Cantor method. Sequences were deposited in the GenBank database under accession numbers MF382054 to MF382079.

\section{Results and discussion}

Bacterial isolation and selection of biosurfactant/ bioemulsifier-producers

After bacterial growth in mMSM broth with glucose, 43 pure isolates selected based on their different colony morphology after several successive streakings on mMSM agar medium, were screened for the BS/BE production. The results of drop collapse, IFT and $\mathrm{EI}_{24}$ of different organic solvents for the producer isolates are reported in Table 1. Among the 43 isolates screened, 26 showed an $\mathrm{EI}_{24}$ higher than $50 \%$ in at least one of the solvents tested. The maximum emulsifying activity was observed between 48 and $72 \mathrm{~h}$ of incubation. In particular, the highest $\mathrm{EI}_{24}$ was observed towards toluene and equal to $75.0 \pm 1.7 \%$. Cell-free culture supernatants of most isolates exhibited a weak drop collapse activity and only few of them were able to slightly decrease the medium surface tension (from $74.7 \pm 0.2$ to $60.2 \pm 1.6 \mathrm{mN} / \mathrm{m}$, Table 1). It has been reported that low-molecular weight BS are able to reduce the surface 
Table 1 List of the 26 bacterial surface-active compounds producers selected among $\mathbf{4 3}$ isolates obtained from marine sediments and grown in $\mathrm{mMSM}$ with $1 \%_{\mathrm{w} / \mathrm{v}}$ glucose as carbon source

\begin{tabular}{|c|c|c|c|c|c|c|c|}
\hline Isolate ID & $\begin{array}{l}\text { 16SrDNA } \\
\text { Accession No }\end{array}$ & $\begin{array}{l}\text { Closest type strain } \\
\text { (GenBank Accession No) }\end{array}$ & $\begin{array}{l}\text { 16S rDNA } \\
\text { identity (\%) }\end{array}$ & $\begin{array}{l}\text { Drop } \\
\text { collapse }\end{array}$ & $\begin{array}{l}\text { IFT } \\
(\mathrm{mN} / \mathrm{m})\end{array}$ & $\begin{array}{l}\mathrm{El}_{24}(\%) \\
\text { Hexane }\end{array}$ & $\begin{array}{l}\mathrm{El}_{24}(\%) \\
\text { Toluene }\end{array}$ \\
\hline M11.30 & MF382057 & Bacillus hwajinpoensis SW-72 (NR_025264) & 99 & - & $71.6 \pm 0.2$ & $16.0 \pm 1.7$ & $49.8 \pm 7.6$ \\
\hline M21.30 & MF382056 & Bacillus hwajinpoensis SW-72 (NR_025264) & 98 & - & $68.4 \pm 0.1$ & $25.0 \pm 2.4$ & $62.7 \pm 0.9$ \\
\hline G3.20 & MF382058 & Halomonas alkaliantarctica strain CRSS (NR_114902.1) & 99 & + & $71.9 \pm 1.7$ & $45.7 \pm 6.1$ & $67.0 \pm 1.7$ \\
\hline G5.20 & MF382059 & Halomonas venusta strain DSM 4743 (NR_042069.1) & 98 & + & $72.0 \pm 0.1$ & $65.0 \pm 1.7$ & $70.0 \pm 0.0$ \\
\hline G6.20 & MF382060 & Halomonas alkaliantarctica strain CRSS (NR_114902.1) & 99 & + & $66.5 \pm 1.6$ & $67.0 \pm 0.0$ & $67.0 \pm 0.0$ \\
\hline P11.20 & MF382061 & Halomonas titanicae BH1 (NR_117300) & 99 & - & $71.5 \pm 0.2$ & $66.7 \pm 0.0$ & $69.0 \pm 0.0$ \\
\hline G2.30 & MF382062 & Thalassospira xiamenensis DSM 17429 (CP004388) & 99 & + & $72.6 \pm 1.2$ & $33.3 \pm 4.7$ & $70.0 \pm 0.0$ \\
\hline G1.30 & MF382065 & $\begin{array}{l}\text { Marinobacter hydrocarbonoclasticus ATCC } 49840 T \\
\text { (NR_074619) }\end{array}$ & 99 & - & $74.4 \pm 0.4$ & $63.3 \pm 4.7$ & $68.3 \pm 2.4$ \\
\hline G19.30 & MF382076 & Marinobacter similis strain A3d10 (KJ547704) & 99 & - & $74.6 \pm 0.1$ & $62.0 \pm 0.0$ & $75.0 \pm 1.7$ \\
\hline M15.20 & MF382063 & Marinobacter salarius strain R9SW1(KJ547705) & 99 & - & $66.7 \pm 0.5$ & $58.6 \pm 4.9$ & $62.1 \pm 4.9$ \\
\hline M18.20 & MF382073 & Marinobacter salarius strain R9SW1(KJ547705) & 99 & - & $70.9 \pm 0.8$ & $63.9 \pm 0.8$ & $66.7 \pm 0.0$ \\
\hline M20.20 & MF382064 & Marinobacter salarius strain R9SWI (KJ547705) & 99 & - & $72.1 \pm 0.1$ & $56.9 \pm 0.3$ & $62.7 \pm 0.9$ \\
\hline M22.20 & MF382072 & Marinobacter salarius strain R9SW1(KJ547705) & 99 & + & $66.5 \pm 1.7$ & $62.0 \pm 1.7$ & $62.0 \pm 0.0$ \\
\hline M24.20 & MF382074 & Marinobacter salarius strain R9SW1 (KJ547705) & 99 & - & $70.3 \pm 1.7$ & $45.0 \pm 7.1$ & $63.0 \pm 6.7$ \\
\hline M27.20 & MF382071 & Marinobacter salarius strain R9SW1(KJ547705) & 98 & + & $69.6 \pm 0.6$ & $57.0 \pm 0.0$ & $55.9 \pm 5.8$ \\
\hline M28.20 & MF382075 & Marinobacter salarius strain R9SW1(KJ547705) & 99 & - & $71.9 \pm 0.1$ & $61.0 \pm 1.5$ & $63.7 \pm 2.4$ \\
\hline M1.30 & MF382066 & Marinobacter flavimaris strain SW-145 (NR_025799.1) & 99 & - & $71.9 \pm 0.1$ & $59.2 \pm 5.8$ & $33.3 \pm 0.0$ \\
\hline M10.30 & MF382067 & Marinobacter guineae strain M3B (NR_042618.1) & 99 & + & $72.0 \pm 0.1$ & $60.0 \pm 0.0$ & $67.0 \pm 0.0$ \\
\hline M13.30 & MF382069 & Marinobacter sediminum strain R65 (NR_029028.1) & 99 & - & $71.9 \pm 0.1$ & $61.0 \pm 1.5$ & $66.1 \pm 0.8$ \\
\hline M17.30 & MF382077 & Marinobacter sediminum strain R65 (NR_029028.1) & 99 & + & $72.3 \pm 0.0$ & $63.3 \pm 0.0$ & $70.0 \pm 0.0$ \\
\hline M24.30 & MF382078 & Marinobacter sediminum strain R65 (NR_029028.1) & 99 & + & $69.7 \pm 1.1$ & $61.7 \pm 2.4$ & $66.7 \pm 0.0$ \\
\hline M25.30 & MF382070 & Marinobacter sediminum strain R65 (NR_029028.1) & 99 & + & $60.2 \pm 1.6$ & $63.0 \pm 0.0$ & $73.0 \pm 0.0$ \\
\hline M26.30 & MF382068 & Marinobacter guineae strain M3B (NR_042618.1) & 99 & + & $72.0 \pm 0.1$ & $53.0 \pm 3.3$ & $68.0 \pm 1.7$ \\
\hline M27.30 & MF382079 & Marinobacter salarius strain R9SW1(KJ547705) & 96 & - & $69.2 \pm 1.2$ & $57.6 \pm 1.4$ & $50.0 \pm 4.7$ \\
\hline M16.30 & MF382055 & Marinobacter salarius strain R9SW1(KJ547705) & 99 & + & $67.1 \pm 1.0$ & $51.7 \pm 5.0$ & $66.7 \pm 0.0$ \\
\hline P7.30 & MF382054 & Marinobacter adhaerens strain HP15 (NR_074765) & 100 & - & $66.8 \pm 1.6$ & $64.4 \pm 1.54$ & $68.3 \pm 0.0$ \\
\hline
\end{tabular}

tension of aqueous media to around $40 \mathrm{mN} / \mathrm{m}$, while the high molecular weight BE often form and stabilize emulsions without remarkable surface tension reduction $[15$, 16]. These results suggest that under these experimental conditions, mainly BE were produced.

\section{S rRNA gene sequencing of the bioemulsifier-producing strains}

The molecular identification of the 26 BS/BE-producing isolates was performed by sequencing the $16 \mathrm{~S}$ rRNA gene and comparing the sequences to the NCBI $16 \mathrm{~S}$ rRNA database. The isolates were shown to belong to the genera Bacillus, Thalassospira, Halomonas and Marinobacter (Table 1, Additional file 1: Figure S1). The results of almost full 16S rRNA gene sequence (1445 bp-long) comparison indicated that isolates M21.30 and M11.30 have the highest sequence similarities of 98 and $99 \%$ with Bacillus hwajinpoensis strain SW-72 isolated from sea water [17]. Phylogenetic analyses of the 1362 bp-long $16 \mathrm{~S}$ rRNA gene sequence placed isolate $\mathrm{G} 2.30$ within the genus Thalassospira. A sequence similarity of 99\% was found with Thalassospira xiamensis strain M-5 isolated from the surface water of a waste oil pool at the oil storage dock in the city of Xiamen [18] and Thalassospira xianhensis strain P-4 isolated from oil-polluted saline soil [19], respectively. At a sequence similarity of $99 \%$ of the 1416 bp-long 16S rRNA gene sequence, the closest type strain relative of isolate P11.20 was Halomonas titanicae $\mathrm{BH} 1$ isolated from the Titanic ship wreck in Atlantic Ocean [20]. The 16S rRNA gene sequences of isolates G3.20 and G6.20 showed similarity of 99\% with strains Halomonas alkaliantarctica strain CRSS obtained from saline lake in Antarctica [21] while that of isolate G5.20 showed similarity of $98 \%$ with the validated species Halomonas venusta strain DSM 4743 [22]. With regard to the isolates belonging to the genus Marinobacter, with the exception of isolate P7.30 that exhibited 100\% similarity with Marinobacter adhaerens strain HP15 [23], each of the other sequences showed a similarity of $99 \%$ with type strain of different species of the genus isolated from 
marine environment $[24,25]$. Many bacteria within these genera could not be identified to the species level based only on 16S rRNA gene sequences [26-28], hence further analyses need to be performed in order to establish the exact phylogenetic positions of the isolates, which is beyond the aim of this study. The obtained results are in line with previous surveys where these bacterial genera have been reported to be indigenous to marine environments $[17,27-30]$. The production of surface-active molecules from marine bacteria has been reported by several authors [31-34]. However, to the best of our knowledge, there have been no reports on the characterization of surface-active molecules production from the Marinobacter and Thalassospira although bacteria within these genera have been often retrieved from hydrocarbonenriched marine communities [35-37]. It is also of note that, we were able to obtain bacteria mainly from the Marinobacter genus starting from sediments subjected to hydrocarbons contamination in the harbors, supporting previous studies reporting on the specialization of bacteria from this genus in lipids and hydrocarbons metabolism [29].

\section{Effect of salinity and temperature on emulsification activity}

The activity of the crude BEs was evaluated from cell-free culture supernatants, recovered after growth on glucosebased media, after exposure to low water activity as well as to high or low temperature (Fig. 1). The emulsification activity was not evaluated towards hexane when high salt concentration, i.e. $300 \mathrm{~g} / \mathrm{l}$ of $\mathrm{NaCl}$, was tested, since even positive controls did not exhibit emulsifying activity towards the solvent under such conditions. Using toluene as organic solvent, in the presence of $300 \mathrm{~g} / \mathrm{l}$ of $\mathrm{NaCl}$, the common chemical surfactant SDS exhibited a reduced emulsifying activity as shown by the decrease of the $\mathrm{EI}_{24}$ to $27 \pm 3.3 \%$ from $77 \pm 3.3 \%$ under standard conditions. On the opposite, with the exception of supernatants from isolates G19.30, M24.20, M28.20 and M13.30, no significant impact on the emulsifying potential was observed; and most of the isolates exhibited an $\mathrm{EI}_{24} \%$ equal to that recorded under standard conditions (Fig. 1a). The effect of thermal treatment on the emulsifier activity showed that, with few exceptions, no appreciable changes has occurred in the emulsification capacity of most

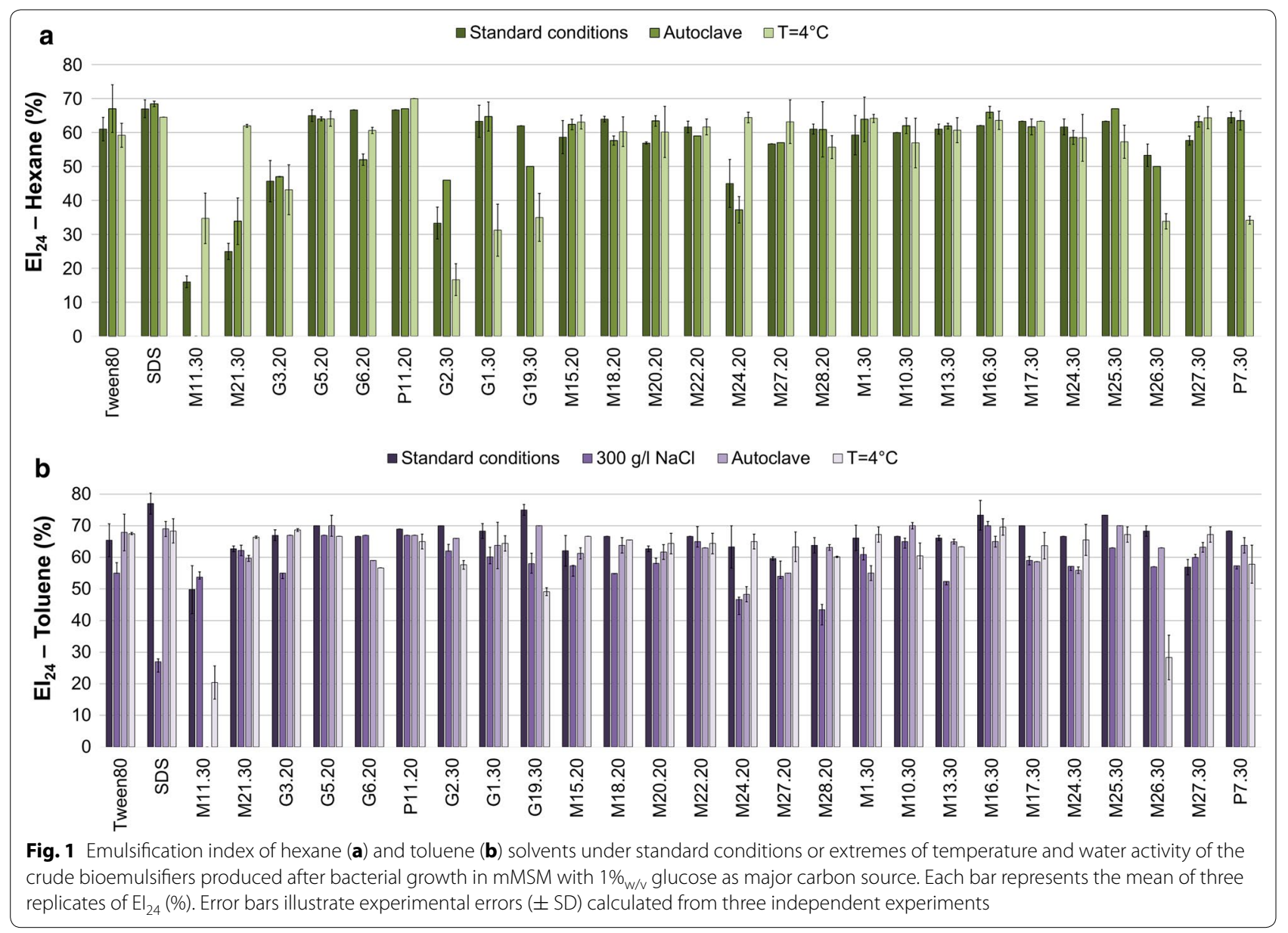


supernatants using both aromatic and aliphatic hydrocarbon solvents (Fig. 1). In specific, a complete loss of emulsification capacity of both solvents was observed in the case of isolate M11.30 after autoclaving $\left(121^{\circ} \mathrm{C}, 20 \mathrm{~min}\right)$; while a decrease of hexane emulsification in the case of supernatants from isolates G1.30, G2.30, G19.30, M26.30 and P7.30 and of that of toluene by G19.30, M11.30 and M26.30 was recorded at $4{ }^{\circ} \mathrm{C}$. On the other hand, the emulsification activity of isolates M24.20, M11.30 and M21.30 towards hexane was shown to be higher at $4{ }^{\circ} \mathrm{C}$ compared to the standard conditions. Higher emulsification activity compared to the standard conditions was also recorded for autoclaved supernatant of G2.30 towards hexane. Gutiérrez et al. [33] reported that heat $\left(100{ }^{\circ} \mathrm{C}\right)$ and acid conditions $(0.1 \mathrm{~N})$ increase the relative activity of the bioemulsifiers produced by Halomonas sp. They referred to this mechanism as heat activation of polymeric emulsifiers, explained by the fact that this treatment may have induced the release of a higher number of emulsifying moieties from these biopolymers that would contribute to their increased emulsifying capacity. $\mathrm{BE}$ that are not affected by $\mathrm{NaCl}$ concentrations up to $300 \mathrm{~g} / \mathrm{l}$ have been described from Paenibacillus sp. \#510 [38]. Dubey et al. [39] evaluated the effect of increasing temperature and salt concentrations on biosurfactant activities of Pseudomonas aeruginosa strain-PP2 and Kocuria turfanesis strain-J and found that both bioemulsifiers retained their activity up to $200 \mathrm{~g} / \mathrm{l} \mathrm{NaCl}$ and to $121{ }^{\circ} \mathrm{C}$. Purified trehalolipid biosurfactant produced by a marine Rhodococcus sp. produced emulsions that were stable to a wide range of temperatures $\left(20-100{ }^{\circ} \mathrm{C}\right)$ and $\mathrm{NaCl}$ concentrations (50-250 g/l) [40]. Currently, we are aware of one study reporting on stable biosurfactant activity at low temperature in the case of Brevibacterium luteolum. However, in that case the assay was performed under slightly different conditions, i.e. evaluation of the surface activity was performed at room temperature after incubating the biosurfactants at $4{ }^{\circ} \mathrm{C}$ for $24 \mathrm{~h}$ [41], while in our case the emulsions were let to form at $4{ }^{\circ} \mathrm{C}$ and using cold culture supernatant and solvents, resulting in stabilizing the formed emulsion. The fact that the produced bioemulsifiers were active at low temperature and high salt concentration is an optimal trait to be considered when application under seawater conditions are targeted.

The obtained results showed that there is no clear correlation between the bacterial growth temperature and the optimal temperature of the bioemulsifier activity. Indeed, independently of the fact that bacteria were grown at 30 or $20{ }^{\circ} \mathrm{C}$, the emulsification capability was strain-specific. The fact that also bioemulsifiers obtained from isolates grown at $30{ }^{\circ} \mathrm{C}$ were highly active at $4{ }^{\circ} \mathrm{C}$ is highly interesting from an industrial viewpoint. Indeed, growing bacteria at $20{ }^{\circ} \mathrm{C}$ would result in extra energy consumption related to bioreactor cooling.

\section{Emulsions stability as a function of time}

The stability of the emulsions produced under standard screening conditions or after exposure to water or heat stress was evaluated as a function of incubation time (Table 2, Additional file 2: Table S1). The emulsions formed showed a high stability at room temperature, maintaining up to $100 \%$ of the original emulsification activity of both solvents over a period of 18 months at $4{ }^{\circ} \mathrm{C}$ and even in the presence of $300 \mathrm{~g} / \mathrm{l}$ of $\mathrm{NaCl}$. Moreover under standard conditions, it was possible to monitor and record a REA of $100 \%$ up to 30 months of incubation in the case of BE produced by Marinobacter sp. strains compared to a REA of 65 or $77.5 \%$ recorded for the controls Tween 80 and SDS, respectively (Table 2). Extended stability in time has been previously observed for the $\mathrm{BE}$ produced by marine Pedobacter sp. strain MCC-Z where the emulsions remained stable for 4 months [42] and for the bioemulsifiers produced by a marine Antarctobacter [32]. However, to the best of our knowledge, no reports on extended stability under low water activity, after thermal treatment conditions or 30 months are available and especially from nonpathogenic marine bacteria such as Marinobacter sp.

\section{Effect of carbon source on biosurfactant/bioemulsifiers production and stability}

The 26 selected isolates were also tested for their growth and surface-active molecules production on a relatively cheap and highly available carbon source. All the isolates were able to grow on mMSM with $2 \%_{\mathrm{v} / \mathrm{v}}$ soybean oil as main carbon source and most of them produced surfaceactive molecules. In specific, 16 isolates including Thalassospira sp. G2.30 and 15 Marinobacter sp. exhibited significant emulsification activity $\left(\mathrm{EI}_{24}>50 \%\right)$ towards at least one of the solvents tested and the highest emulsification index was equal to $71.4 \pm 0.0 \%$ towards toluene (Fig. 2a). Cell-free culture supernatants of most isolates exhibited a high drop collapse activity (data not shown) and were able to decrease the medium surface tension from $74.66 \pm 0.21$ up to $34.35 \pm 1.73 \mathrm{mN} / \mathrm{m}$ (Fig. 2a). These results suggest that most of the isolates were able to produce $\mathrm{BE}$ that are able to reduce the surface tension. The supernatants of isolates P11.20 and G19.30 did not exhibit bioemulsification activity towards the solvents tested. They however reduced only slightly the medium surface tension which suggests the production of $\mathrm{BE}$ that are not able to emulsify the toluene and hexane, since slight IFT reduction is often characteristic of BEs. The cell-free culture supernatant of isolate M16.30 did not 
Table 2 Residual emulsification activity (REA) (\%) after 18 or 30 months* of incubation of bioemulsifiers produced by the isolates grown on $\mathrm{mMSM}$ with $1 \%_{\mathrm{w} / \mathrm{v}}$ glucose as carbon source and positive controls

\begin{tabular}{|c|c|c|c|c|c|c|c|}
\hline \multirow{2}{*}{$\begin{array}{l}\text { Bacterial isolate/positive } \\
\text { control }\end{array}$} & \multicolumn{3}{|l|}{ Hexane } & \multicolumn{4}{|l|}{ Toluene } \\
\hline & Standard conditions & Autoclave & $4^{\circ} \mathrm{C}$ & Standard conditions & $300 \mathrm{~g} / \mathrm{l} \mathrm{NaCl}$ & Autoclave & $4^{\circ} \mathrm{C}$ \\
\hline Tween 80 & ${ }^{*} 65.00 \pm 0.00$ & ${ }^{*} 0.00 \pm 0.00$ & $98.44 \pm 0.55$ & ${ }^{*} 86.36 \pm 0.00$ & ${ }^{*} 0.00 \pm 0.00$ & ${ }^{*} 0.00 \pm 0.00$ & $79.93 \pm 10.82$ \\
\hline SDS & $* 77.50 \pm 0.00$ & ${ }^{*} 0.00 \pm 0.00$ & $95.58 \pm 3.65$ & ${ }^{*} 65.73 \pm 0.00$ & *14.30 \pm 0.00 & ${ }^{*} 0.00 \pm 0.00$ & $83.05 \pm 4.66$ \\
\hline Bacillus sp. M11.30 & $0.00 \pm 0.00$ & NA & $0.00 \pm 0.00$ & $43.27 \pm 2.16$ & $23.21 \pm 4.42$ & NA & $0.00 \pm 0.00$ \\
\hline Bacillus sp. M21.30 & $* 64.09 \pm 4.06$ & $93.64 \pm 6.14$ & $97.84 \pm 0.77$ & $* 18.59 \pm 0.93$ & $87.50 \pm 4.13$ & $83.72 \pm 5.55$ & $96.86 \pm 0.61$ \\
\hline Halomonas sp. G3.20 & $57.28 \pm 2.86$ & $86.44 \pm 4.32$ & $39.06 \pm 1.95$ & $82.92 \pm 4.15$ & $51.14 \pm 2.56$ & $0.00 \pm 0.00$ & $85.37 \pm 6.55$ \\
\hline Halomonas sp. G5.20 & $86.84 \pm 0.36$ & $58.59 \pm 2.93$ & $96.25 \pm 0.36$ & $67.97 \pm 4.89$ & $55.97 \pm 2.80$ & $23.04 \pm 1.15$ & $87.93 \pm 0.00$ \\
\hline Halomonas sp. G6.20 & $55.56 \pm 2.78$ & $0.00 \pm 0.00$ & $79.61 \pm 1.20$ & $85.00 \pm 4.25$ & $79.29 \pm 3.96$ & $99.36 \pm 4.97$ & $91.28 \pm 0.00$ \\
\hline Halomonas sp. P11.20 & $95.89 \pm 1.25$ & $89.55 \pm 4.48$ & $84.73 \pm 1.39$ & $56.42 \pm 2.82$ & $93.28 \pm 4.66$ & $38.52 \pm 1.93$ & $94.48 \pm 1.95$ \\
\hline Thalassospira sp. G2.30 & $0.00 \pm 0.00$ & $0.00 \pm 0.00$ & $84.82 \pm 6.31$ & $0.00 \pm 0.00$ & $100.00 \pm 0.00$ & $0.00 \pm 0.00$ & $85.25 \pm 8.68$ \\
\hline Marinobacter sp. G1.30 & $* 92.12 \pm 7.89$ & $82.37 \pm 1.82$ & $89.09 \pm 6.29$ & $* 80.36 \pm 7.58$ & $89.00 \pm 7.24$ & $81.70 \pm 5.68$ & $93.69 \pm 0.30$ \\
\hline Marinobacter sp. G19.30 & $0.00 \pm 0.00$ & $0.00 \pm 0.00$ & $46.13 \pm 2.10$ & $0.00 \pm 0.00$ & $0.00 \pm 0.00$ & $0.00 \pm 0.00$ & $87.12 \pm 8.12$ \\
\hline Marinobacter sp. M15.20 & $* 74.71 \pm 9.25$ & $53.38 \pm 1.32$ & $76.39 \pm 1.54$ & $* 90.02 \pm 6.68$ & $88.91 \pm 7.25$ & $88.51 \pm 1.09$ & $95.69 \pm 3.66$ \\
\hline Marinobacter sp. M18.20 & $* 78.25 \pm 4.84$ & $97.42 \pm 0.08$ & $80.10 \pm 1.63$ & ${ }^{*} 90.00 \pm 0.00$ & $71.98 \pm 9.96$ & $88.05 \pm 1.18$ & $94.74 \pm 0.00$ \\
\hline Marinobacter sp. M20.20 & $* 25.21 \pm 1.26$ & $74.48 \pm 8.04$ & $78.98 \pm 0.05$ & $* 97.93 \pm 2.92$ & $93.44 \pm 2.24$ & $89.53 \pm 3.42$ & $92.58 \pm 0.74$ \\
\hline Marinobacter sp. M22.20 & $87.11 \pm 4.36$ & $56.50 \pm 2.82$ & $95.13 \pm 3.64$ & $100.00 \pm 0.00$ & $86.54 \pm 4.33$ & $84.33 \pm 4.22$ & $100.00 \pm 0.00$ \\
\hline Marinobacter sp. M24.20 & $* 85.38 \pm 5.52$ & $0.00 \pm 0.00$ & $98.06 \pm 0.08$ & *90.55 \pm 9.63 & $0.00 \pm 0.00$ & $0.00 \pm 0.00$ & $95.55 \pm 3.46$ \\
\hline Marinobacter sp. M27.20 & $* 100.00 \pm 0.00$ & $33.96 \pm 1.70$ & $90.27 \pm 7.03$ & *89.88 \pm 9.26 & $11.57 \pm 0.58$ & $72.73 \pm 3.64$ & $93.33 \pm 4.39$ \\
\hline Marinobacter sp. M28.20 & $* 64.48 \pm 9.82$ & $35.93 \pm 9.80$ & $81.85 \pm 6.03$ & $* 95.24 \pm 3.64$ & $35.63 \pm 0.11$ & $77.81 \pm 0.80$ & $87.23 \pm 2.35$ \\
\hline Marinobacter sp. M1.30 & $* 98.94 \pm 0.00$ & $88.95 \pm 7.85$ & $55.60 \pm 6.85$ & $* 88.96 \pm 2.47$ & $91.98 \pm 0.12$ & $90.78 \pm 0.71$ & $92.37 \pm 3.35$ \\
\hline Marinobacter sp. M10.30 & $91.49 \pm 7.47$ & $95.77 \pm 4.79$ & $79.60 \pm 5.28$ & $96.77 \pm 0.00$ & $93.24 \pm 4.66$ & $89.29 \pm 4.46$ & $77.07 \pm 2.65$ \\
\hline Marinobacter sp. M13.30 & $* 69.84 \pm 9.26$ & $79.41 \pm 3.07$ & $89.34 \pm 4.56$ & $* 96.51 \pm 2.50$ & $92.27 \pm 2.62$ & $91.84 \pm 1.17$ & $87.22 \pm 4.25$ \\
\hline Marinobacter sp. M16.30 & $85.93 \pm 7.59$ & $83.20 \pm 4.16$ & $94.44 \pm 4.04$ & $91.10 \pm 5.86$ & $85.25 \pm 4.26$ & $93.38 \pm 4.67$ & $93.27 \pm 2.19$ \\
\hline Marinobacter sp. M17.30 & $* 90.23 \pm 4.51$ & $87.84 \pm 2.31$ & $100.00 \pm 0.00$ & $* 85.71 \pm 4.29$ & $100.00 \pm 0.00$ & $92.75 \pm 1.93$ & $96.20 \pm 2.94$ \\
\hline Marinobacter sp. M24.30 & $* 11.19 \pm 0.43$ & $87.04 \pm 5.24$ & $64.11 \pm 9.44$ & *95.00 \pm 0.00 & $97.54 \pm 0.07$ & $82.97 \pm 6.41$ & $95.52 \pm 3.25$ \\
\hline Marinobacter sp. M25.30 & $69.14 \pm 6.43$ & $84.11 \pm 4.21$ & $62.20 \pm 3.54$ & $83.58 \pm 4.18$ & $84.33 \pm 4.22$ & $90.17 \pm 4.51$ & $90.79 \pm 1.12$ \\
\hline Marinobacter sp. M26.30 & $0.00 \pm 0.00$ & $50.00 \pm 2.50$ & $49.32 \pm 3.32$ & $63.59 \pm 7.82$ & $82.59 \pm 4.13$ & $71.68 \pm 3.58$ & $41.38 \pm 2.07$ \\
\hline Marinobacter sp. M27.30 & $* 93.40 \pm 3.01$ & $87.04 \pm 5.24$ & $93.91 \pm 5.53$ & $* 87.05 \pm 8.21$ & $97.22 \pm 3.93$ & $93.83 \pm 2.33$ & $92.94 \pm 0.39$ \\
\hline Marinobacter sp. P7.30 & $* 100.00 \pm 0.00$ & $75.58 \pm 4.76$ & $97.62 \pm 3.37$ & $* 99.26 \pm 1.04$ & $93.15 \pm 2.65$ & $94.59 \pm 0.21$ & $78.33 \pm 7.07$ \\
\hline
\end{tabular}

$\mathrm{NA}$ not applicable (the stability was not monitored when no $\mathrm{El}_{24}$ was recorded)

emulsify the solvents tested but was able to exhibit an IFT value of $44.7 \pm 0.8 \mathrm{mN} / \mathrm{m}$ (Fig. 2a).

In order to evaluate the stability of the produced emulsions, the cell free culture supernatants of BE producers were subjected to temperature (high and low) and water $(300 \mathrm{~g} / \mathrm{l} \mathrm{NaCl})$ stresses (Fig. 2b, c). Cell free-culture supernatants were able to highly emulsify toluene with the exception of those of isolates M10.30, M15.20 and G2.30 for which a significant decrease or loss of the activity was observed after autoclaving or in the presence of $300 \mathrm{~g} / \mathrm{l} \mathrm{NaCl}$, respectively. The low temperature did not affect the emulsifying ability of the crude bioemulsifiers of almost all the isolates towards both solvents, except for M26.30 and M10.30, which exhibited a higher emulsification index of hexane at this temperature.
Furthermore, similarly to the $\mathrm{BE}$ produced after growth in glucose-based media, the produced emulsions were stable under the different conditions tested up to 18 months of incubation at room temperature retaining up to $100 \%$ of the activity displayed under standard conditions (Table 3).

\section{Preliminary chemical characterization}

Partially purified BS/BE obtained by acid precipitation from cell-free culture supernatants of the isolates exhibiting significant surface activity after growth in soybeanbased medium, were subjected to FT-IR analysis for the identification of the main functional groups present. All the samples show the main absorption bands of a polypeptide, that is to say amide I and II: at $1654 \mathrm{~cm}^{-1}$ and 


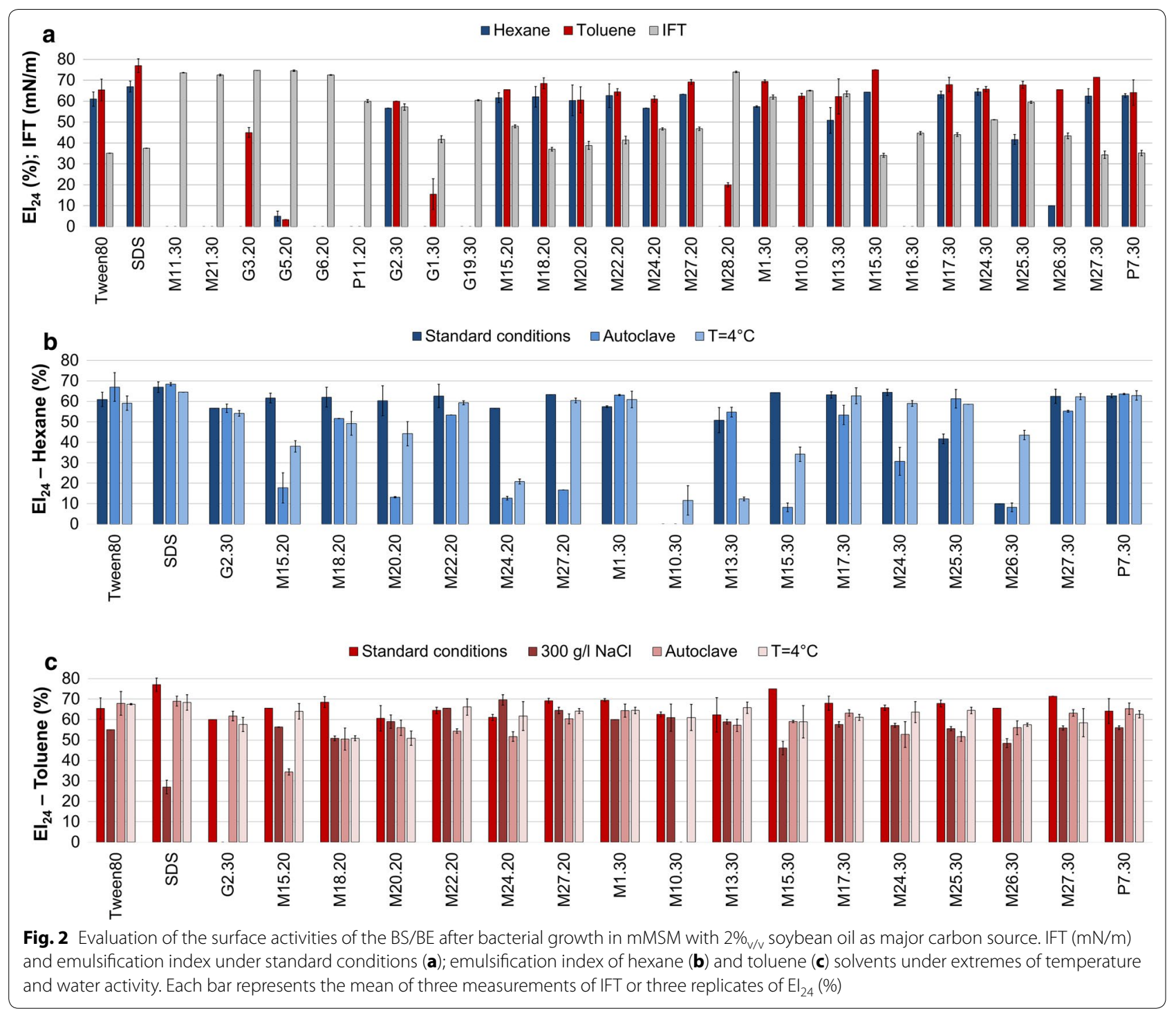

around $1540 \mathrm{~cm}^{-1}$ the stretching mode of the CO-N bond and the bending mode of $\mathrm{NH}$ bond are present. In some samples the band of $\mathrm{CO}-\mathrm{N}$ has two peaks, therefore two conformation are probably present $[43,44]$. In addition, all the spectra disclosed a broad stretching peak into the region $3100-3400 \mathrm{~cm}^{-1}$ characteristic of $\mathrm{N}-\mathrm{H}$ and $\mathrm{O}-\mathrm{H}$ groups. Absorptions around $2960 \mathrm{~cm}^{-1}$ are assigned to the symmetric $\mathrm{C}-\mathrm{H}$ stretch of $\mathrm{CH}_{2}$ and $\mathrm{CH}_{3}$ groups of aliphatic chains. The asymmetric and symmetric stretching of phosphate anion can be found at almost 1236 and $1070 \mathrm{~cm}^{-1}$, respectively [45]. The typical carbonyl stretching group $(\mathrm{C}=\mathrm{O})$, indicating of an ester, is present in almost all samples at about $1740 \mathrm{~cm}^{-1}$. Therefore, the FT-IR spectra suggested that, with the exception of M16.30, M15.20 and M26.30 which seem to produce phosphopeptides BS, the produced surface active compounds belong to the phospholipopeptide class of BS for almost all the isolates tested (Fig. 3). Lipoprotein bioemulsifiers have been reported from Pseudomonas nitroreducens isolated from a mangrove ecosystem [46]. Protein surface-active compounds from Acinetobacter have been reported to highly emulsify organic solvents [47] while no reports are available on their ability to reduce surface tension. Anionic residues such as phosphates and sulfates have been reported to play an important role in the emulsification of $n$-hexadecane by the EPS produced by Halomonas sp. [48]. Hence, the absence of emulsification activity of the phosphopeptide-producer Marinobacter sp. M16.30 could be that the produced compound is of small molecular weight and therefore is not able to emulsify the organic solvents tested in this study. 
Table 3 Residual activity (REA, \%) after 18 months of incubation of crude bioemulsifiers produced by the isolates grown on $\mathrm{mMSM}$ with $2 \% \mathrm{v} / \mathrm{v}$ soybean oil as main carbon source

\begin{tabular}{|c|c|c|c|c|c|c|c|}
\hline \multirow[t]{2}{*}{ Bacterial isolate } & \multicolumn{3}{|l|}{ HEXANE } & \multicolumn{4}{|l|}{ TOLUENE } \\
\hline & Standard conditions & Autoclave & $4^{\circ} \mathrm{C}$ & Standard conditions & $300 \mathrm{~g} / \mathrm{l} \mathrm{NaCl}$ & Autoclave & $4^{\circ} \mathrm{C}$ \\
\hline Thalassospira sp. G2.30 & $58.82 \pm 2.94$ & $32.16 \pm 1.99$ & $85.69 \pm 2.18$ & $66.67 \pm 3.33$ & $0.00 \pm 0.00$ & $75.32 \pm 7.27$ & $92.48 \pm 7.38$ \\
\hline Marinobacter sp. M15.20 & $63.89 \pm 8.48$ & $0.00 \pm 0.00$ & $52.86 \pm 9.28$ & $97.37 \pm 3.72$ & $94.46 \pm 4.29$ & $86.81 \pm 8.90$ & $93.95 \pm 5.58$ \\
\hline Marinobacter sp. M18.20 & $76.35 \pm 4.04$ & $86.45 \pm 4.83$ & $76.97 \pm 0.87$ & $100.00 \pm 0.00$ & $66.77 \pm 3.10$ & $67.67 \pm 8.79$ & $98.33 \pm 2.36$ \\
\hline Marinobacter sp. M20.20 & $62.50 \pm 3.13$ & $0.00 \pm 0.00$ & $92.64 \pm 4.63$ & $82.59 \pm 8.88$ & $94.43 \pm 0.44$ & $58.57 \pm 2.41$ & $34.16 \pm 6.55$ \\
\hline Marinobacter sp. M22.20 & $67.52 \pm 9.06$ & $66.96 \pm 3.35$ & $90.16 \pm 5.59$ & $100.00 \pm 0.00$ & $77.47 \pm 9.93$ & $96.94 \pm 0.22$ & $94.87 \pm 0.19$ \\
\hline Marinobacter sp. M24.20 & $92.80 \pm 6.45$ & $86.21 \pm 8.28$ & $68.68 \pm 3.89$ & $100.00 \pm 0.00$ & $90.00 \pm 4.50$ & $93.41 \pm 4.09$ & $97.50 \pm 3.54$ \\
\hline Marinobacter sp. M27.20 & $88.30 \pm 9.10$ & $69.64 \pm 7.58$ & $63.80 \pm 7.83$ & $94.83 \pm 0.58$ & $78.95 \pm 0.00$ & $85.51 \pm 4.78$ & $96.75 \pm 1.78$ \\
\hline Marinobacter sp. M1.30 & $93.75 \pm 8.84$ & $86.02 \pm 9.24$ & $83.73 \pm 7.57$ & $87.83 \pm 1.18$ & $83.33 \pm 4.06$ & $90.00 \pm 2.92$ & $93.74 \pm 6.03$ \\
\hline Marinobacter sp. M10.30 & NA & NA & $92.86 \pm 6.64$ & $94.83 \pm 0.58$ & $65.61 \pm 0.60$ & NA & $69.03 \pm 2.60$ \\
\hline Marinobacter sp. M13.30 & $100.00 \pm 0.00$ & $52.00 \pm 6.99$ & $87.44 \pm 6.22$ & $87.30 \pm 6.42$ & $94.99 \pm 0.05$ & $82.79 \pm 7.05$ & $94.33 \pm 1.19$ \\
\hline Marinobacter sp. M17.30 & $87.62 \pm 5.04$ & $81.62 \pm 9.36$ & $89.67 \pm 1.10$ & $97.37 \pm 3.72$ & $83.77 \pm 2.01$ & $90.38 \pm 5.75$ & $90.38 \pm 5.75$ \\
\hline Marinobacter sp. M24.30 & $94.27 \pm 2.26$ & $40.89 \pm 0.89$ & $97.51 \pm 3.52$ & $0.00 \pm 0.00$ & $86.10 \pm 0.55$ & $88.56 \pm 6.08$ & $92.44 \pm 7.44$ \\
\hline Marinobacter sp. M25.30 & $0.00 \pm 0.00$ & $35.06 \pm 2.61$ & $85.29 \pm 4.16$ & $94.14 \pm 5.85$ & $35.94 \pm 7.84$ & $32.41 \pm 6.55$ & $92.11 \pm 3.72$ \\
\hline Marinobacter sp. M26.30 & $65.59 \pm 1.52$ & $0.00 \pm 0.00$ & $99.34 \pm 0.94$ & $92.65 \pm 5.69$ & $43.89 \pm 6.20$ & $67.29 \pm 3.70$ & $92.74 \pm 6.87$ \\
\hline Marinobacter sp. M27.30 & $95.37 \pm 5.57$ & $27.08 \pm 7.75$ & $97.37 \pm 3.72$ & $100.00 \pm 0.00$ & $87.87 \pm 0.52$ & $90.48 \pm 2.24$ & $87.76 \pm 6.79$ \\
\hline Marinobacter sp. P7.30 & $96.84 \pm 1.38$ & $90.99 \pm 9.92$ & $99.08 \pm 1.30$ & $93.99 \pm 8.42$ & $89.28 \pm 1.48$ & $95.16 \pm 4.03$ & $98.59 \pm 0.98$ \\
\hline
\end{tabular}

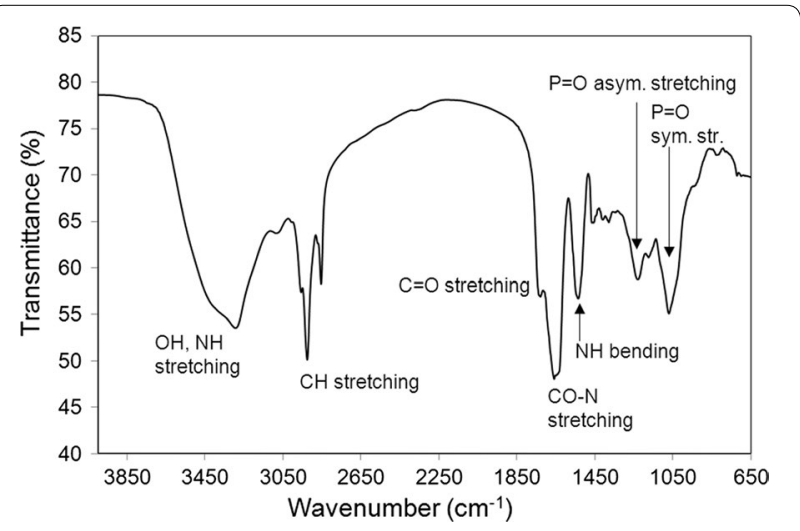

Fig. 3 Example of a phospholipopeptide FTIR spectrum of partially purified BS/BE produced by one of the isolates (Marinobacter sp. M22.20) after growth in $\mathrm{mMSM}$ with $2 \%$ v/v soybean oil as major carbon source; asym. and sym. str: asymmetric and symmetric stretching of phosphate anion

\section{Critical micelle concentration}

The determination of biosurfactants CMC is crucial since there is no further modification in the surfactant activity above this concentration. The CMCs were determined on partially purified biosurfactants obtained from cellfree culture supernatants (after growth in the presence of $2 \%_{\mathrm{v} / \mathrm{v}}$ soybean oil as major carbon source) through acid precipitation. The CMCs of the biosurfactants produced by the 11 isolates (that were able to reduce surface tension to values $\leq 45 \mathrm{mN} / \mathrm{m}$ ) were estimated to range between 2520 and $620 \mathrm{mg} / \mathrm{l}$ among the different isolates (Table 4). These values are higher compared to those reported for chemical biosurfactants like Tween 80 $(110 \mathrm{mg} / \mathrm{l})$ [39] or Triton X-100 (150 mg/l) and to other

Table 4 Toxicity data obtained for the different BS/BE produced by the isolates after growth on mMSM with $2 \% \%_{v / v}$ soybean oil as carbon source

\begin{tabular}{|c|c|c|}
\hline Sample & $\begin{array}{l}\text { Concentration } \\
\text { tested (mg/l) }\end{array}$ & $\begin{array}{l}\mathrm{EC}_{50}(\mathrm{mg} / \mathrm{l}) \\
\text { after } 30 \mathrm{~min}\end{array}$ \\
\hline SDS & 1000 & $110.99 \pm 16.36$ \\
\hline Marinobacter sp. G1.30 & 620 & $3.10 \pm 1.85$ \\
\hline Marinobacter sp. M15.20 & 1000 & $380.70 \pm 39.46$ \\
\hline Marinobacter sp. M18.20 & 1620 & $194.05 \pm 59.59$ \\
\hline Marinobacter sp. M20.20 & 2350 & ND \\
\hline Marinobacter sp. M22.20 & 1560 & ND \\
\hline Marinobacter sp. M24.20 & 1320 & $24.13 \pm 11.62$ \\
\hline Marinobacter sp. M27.20 & 2070 & $113.54 \pm 23.69$ \\
\hline Marinobacter sp. M1.30 & 1000 & $58.94 \pm 35.22$ \\
\hline Marinobacter sp. M13.30 & 1000 & $31.91 \pm 12.02$ \\
\hline Marinobacter sp. M16.30 & 2520 & ND \\
\hline Marinobacter sp. M17.30 & 970 & $549.58 \pm 59.10$ \\
\hline Marinobacter sp. M24.30 & 1000 & $77.21 \pm 6.96$ \\
\hline Marinobacter sp. M25.30 & 1000 & $60.95 \pm 20.57$ \\
\hline Marinobacter sp. M26.30 & 2350 & $131.54 \pm 14.90$ \\
\hline Marinobacter sp. M27.30 & 1390 & $118.08 \pm 19.67$ \\
\hline Marinobacter sp. P7.30 & 1580 & $93.72 \pm 35.22$ \\
\hline
\end{tabular}

The partially purified BS were used at their CMCs while a concentration of $1000 \mathrm{mg} / \mathrm{l}$ was tested in the case of BE and SDS. The values are those obtained from three independent experiments $( \pm S D)$. ND: not determined, the increase in bioluminescence did not allow calculating the $\mathrm{EC}_{50}$ value 
marine bacteria such as Streptomyces sp. (36 mg/l) [49], Brevibacterium luteolum (40 mg/l) [41] and Halomonas sp. MB-30 (250 mg/l) [50]. On the other hand, they are in agreement with $\mathrm{BE} / \mathrm{BS}$ produced by different bacterial species like the purified bioemulsifier produced by Pedobacter sp. strain MCC-Z, a glycolipids-protein complex, that showed high emulsifying activity $\left(\mathrm{EI}_{24}=64 \%\right)$ and reduced the surface tension of water up to $41 \mathrm{mN} / \mathrm{m}$ with a critical micelle concentration value of $2600 \mathrm{mg} / \mathrm{l}$ [42]. The comparison with Marinobacter sp. is not possible since, to the best of our knowledge, no reports on characterization of BS produced by bacteria from this genus are available.

\section{Ecotoxicity assays}

The toxicity of the BE/BS produced by the bacterial isolates and of the synthetic surfactant SDS was assessed using $V$. fischeri as an indicator microorganism. The partially purified BS were used at their CMCs while a concentration of $1000 \mathrm{mg} / \mathrm{l}$ was tested in the case of BE. The $\mathrm{EC}_{50}$ values obtained are shown in Table 4. After $30 \mathrm{~min}$ of exposure, the $\mathrm{EC}_{50}$ values of several (6/17) of the tested isolates were higher compared to that of SDS. Specifically, the $\mathrm{EC}_{50}$ of SDS used at $1000 \mathrm{mg} / \mathrm{l}$ was equal to $110.99 \pm 16.36 \mathrm{mg} / \mathrm{l}$ while those of most of the isolates ranged between $113.54 \pm 23.69$ and $549.58 \pm 59.10 \mathrm{mg} / \mathrm{l}$. Interestingly, for three Marinobacter sp. isolates (M20.20, M22.20 and M16.30), it was not possible to calculate the $\mathrm{EC}_{50}$ value since an increase of the bioluminescence was observed; this indicates the nontoxic character of the tested biosurfactants. On the contrary, several isolates exhibited higher toxicity towards $V$. fischeri at the concentrations tested (Table 4). Although it is difficult to compare and discuss in deep the obtained data with those available in literature due to the lack of a unique way to report the results of ecotox assays towards $V$. fischeri, it is possible to conclude that the BE/BS from Marinobacter sp. isolates exhibit similar or less toxicity when compared with other microbial surface-active compounds. In similar assays, Lima et al. [5] reported $\mathrm{EC}_{20}$ values for different bacterial biosurfactants between 261 and $736 \mathrm{mg} / \mathrm{l}$. Gudiña et al. [38] reported that $V$. fischeri bioluminescence was reduced by $29 \%$ after 30 min exposure to the bioemulsifier produced by Paenibacillus sp. at a concentration of $1000 \mathrm{mg} / \mathrm{l}$. Franzetti et al. [51] reported a low toxicity for the bioemulsifier produced by Variovorax paradoxus $7 \mathrm{bCT} 5$ against $V$. fischeri, with $34 \pm 2 \%$ bioluminescence inhibition after $15 \mathrm{~min}$ of exposure to the highest concentration tested (500 mg/l).

\section{Evaluation of the dispersant ability of the surface active compounds}

Solutions of the partially purified surface-active compounds prepared at the same concentrations as those applied for ecotox assays were used in oil spreading test. Figure 4 illustrates the crude oil dispersant capacity of the BS/BE in artificial sea water. Compared to SDS used as control which exhibited a spreading diameter of $8.5 \pm 0.1 \mathrm{~cm}$, the solutions of the partially purified BS/BE showed spreading diameters ranging between $3.6 \pm 0.4$ and $6.4 \pm 0.2 \mathrm{~cm}$. The oil spreading ability observed here is higher compared to that reported by Sriram et al. [52] for lipopeptide BS produced by Escherichia fergusonii, which exhibited an oil spreading diameter of $2.66 \pm 0.20 \mathrm{~cm}$ in the presence of $30 \mathrm{~g} / \mathrm{l} \mathrm{NaCl}$. A higher spreading diameter i.e. $19 \mathrm{~cm}$ was recorded for a lipopeptide produced by Bacillus atrophaeus 5-2a but the assay was performed using paraffine oil [2].

\section{Conclusions}

A collection of marine bacteria, mainly belonging to Marinobacter sp., able to produce BS/BE was established. The bioemulsifiers were active and stable under extremes of temperature, low water activity and up to 30 months of incubation. Further, they exhibited good environmental compatibility as shown by their low ecotoxicity and were able to disperse crude oil in artificial marine water. Owing to these characteristics, the produced BS/ $\mathrm{BE}$ would be very interesting for developing biodispersant formulations to be applied for the bioremediation 
b

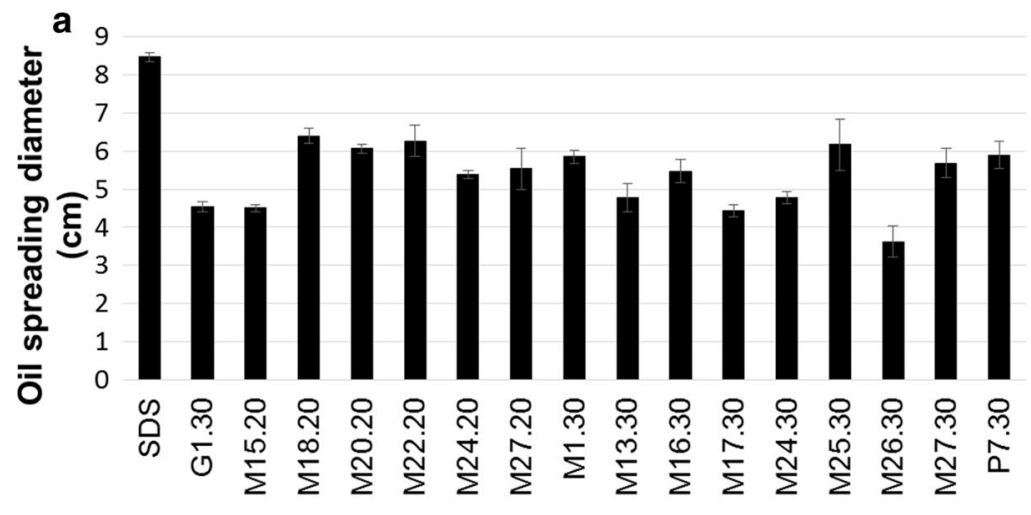

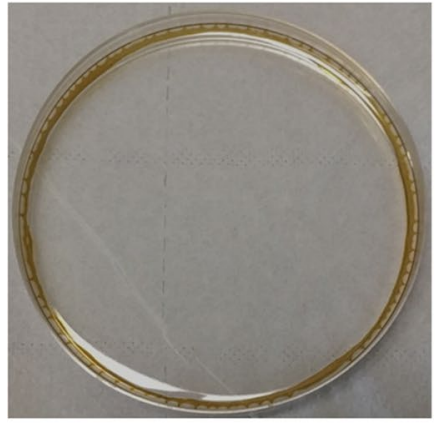

SDS

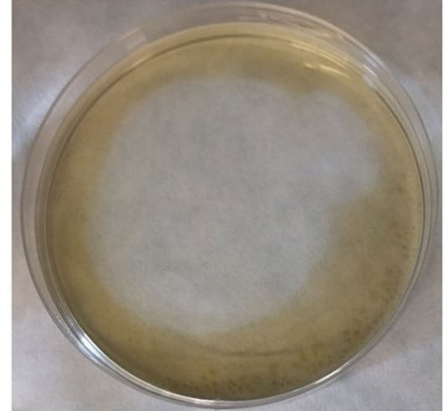

P7.30

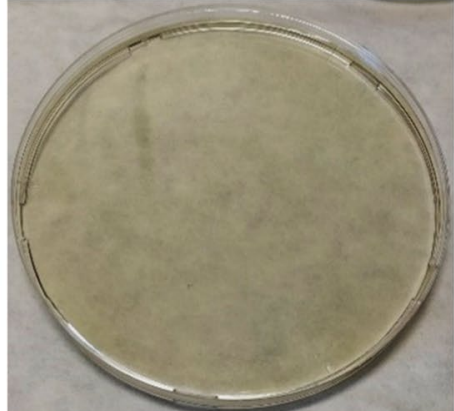

Water

Fig. 4 Crude oil dispersant activities in artificial seawater of partially purified biosurfactants/bioemulsifiers obtained from Marinobacter sp. isolates after growth in $\mathrm{mMSM}$ with $2 \%$ s soybean oil as major carbon source. a Diameter of oil spreading; error bars illustrate experimental errors ( \pm SD) calculated from three independent experiments; $\mathbf{b}$ Example of dispersant activities to crude oil with SDS, water or partially purified BS/BE isolated from Marinobacter sp. P7.30

of marine oil spills. Furthermore, Marinobacter sp. are considered nonpathogenic; and hence are suitable for BS/ $\mathrm{BE}$ large scale production. Studies towards evaluating the ecosustainability of pilot scale production are in progress.

\section{Additional files}

Additional file 1. Phylogenetic affiliation of the almost entire $16 \mathrm{~S}$ rRNA gene of the bacterial isolates constructed using MEGA6 package. Neighbor-Joining phylogenetic tree was built using MEGA6, computing the evolutionary distances using the Jukes-Cantor method.

Additional file 2: Table S1. Residual emulsification activity (REA) (\%) under standard conditions after 18 of incubation of bioemulsifiers produced by the 14 isolates grown on mMSM with $1 \%_{w / v}$ glucose as carbon source.

\section{Authors' contributions}

NR designed the study and wrote the manuscript. LG isolated the bioemulsifier-producing strains and performed the studies related to bioemulsifiers production and functional characterization. GT performed the studies related to the chemical characterization of the bioemulsifier. FF participated in the design of the study. All authors read and approved the final manuscript.

\section{Competing interests}

The authors declare that they have no competing interests.

\section{Availability of data and materials}

Partial 16S rDNA sequences obtained within this work are available at GenBank under the accession numbers listed in the text. All data generated or analyzed during this study are included in this published article (and its Additional files 1 and 2).

\section{Funding}

This work was financially supported by EU FP-7 Project No. 312139"Integrated Biotechnological Solutions for Combating Marine Oil Spills"—KILL SPILL.

\section{Publisher's Note}

Springer Nature remains neutral with regard to jurisdictional claims in published maps and institutional affiliations.

Received: 31 July 2017 Accepted: 24 October 2017

Published online: 02 November 2017

\section{References}

1. Satpute SK, Banpurkar AG, Dhakephalkar PK, Banat IM, Chopade BA. Methods for investigating biosurfactants and bioemulsifiers: a review. Crit Rev Biotechnol. 2010:30:127-44.

2. Zhang J, Xue Q, Gao H, Lai H, Wang P. Production of lipopeptide biosurfactants by Bacillus atrophaeus 5-2a and their potential use in microbial enhanced oil recovery. Microb Cell Fact. 2016;15:168-79.

3. Shete AM, Wadhawa G, Banat IM, Chopade BA. Mapping of patents on bioemulsifier and biosurfactant: a review. J Sci Ind Res. 2006;65:91-115. 
4. Kleindienst S, Seidel M, Ziervogel K, Grim S, Loftis K, Harrison S, Malkin SY, Perkins MJ, Field J, Sogin ML, Dittmar T, Passow U, Medeiros PM, Joye SB. Chemical dispersants can suppress the activity of natural oil-degrading microorganisms. Proc Natl Acad Sci USA. 2015;112:14900-5.

5. Lima TM, Procópio LC, Brandão FD, Leão BA, Tótola MR, Borges AC. Evaluation of bacterial surfactant toxicity towards petroleum degrading microorganisms. Bioresour Technol. 2011;102:2957-64.

6. Sen S, Borah SN, Bora A, Deka S. Production, characterization, and antifungal activity of a biosurfactant produced by Rhodotorula babjevae YS3. Microb Cell Fact. 2017;16:95-109.

7. Simpson DR, Natraj NR, Mclnerney MJ, Duncan KE. Biosurfactantproducing Bacillus are present in produced brines from Oklahoma oil reservoirs with a wide range of salinities. Appl Microbiol Biotechnol. 2011;91:1083-93.

8. Cai Q, Zhang B, Chen B, Zhu Z, Lin W, Cao T. Screening of biosurfactant producers from petroleum hydrocarbon contaminated sources in cold marine environments. Mar Pollut Bull. 2014;86:402-10.

9. Deser C, Alexander MA, Xie SP, Phillips AS. Sea surface temperature variability: patterns and mechanisms. Ann Rev Mar Sci. 2010;2:115-43.

10. Jackson SA, Borchert E, O'Gara F, Dobson AD. Metagenomics for the discovery of novel biosurfactants of environmental interest from marine ecosystems. Curr Opin Biotechnol. 2015;33:176-82.

11. Gutierrez T, Berry D, Yang T, Mishamandani S, McKay L, Teske A, Aitken MD. Role of bacterial exopolysaccharides (EPS) in the fate of the oil released during the deepwater horizon oil spill. PLoS ONE. 2013;8:e67717.

12. Cooper DG, Goldenberg BG. Surface-active agents from two Bacillus species. Appl Environ Microbiol. 1987;53:224-9.

13. Wright ES, Safak Yilmaz L, Noguera DR. DECIPHER, a search-based approach to chimera identification for $16 \mathrm{~S}$ rRNA sequences. Appl Environ Microbiol. 2012;78:717-25.

14. Tamura K, Stecher G, Peterson D, Filipski A, Kumar S. MEGA6: molecular evolutionary genetics analysis version 6.0. Mol Biol Evol. 2013;30:2725-9.

15. Bodour AA, Miller-Maier RM. Application of a modified drop-collapse technique for surfactant quantitation and screening of biosurfactantproducing microorganisms. J Microbiol Methods. 1998;32:273-80.

16. Burch AY, Browne PJ, Dunlap CA, Price NP, Lindow SE. Comparison of biosurfactant detection methods reveals hydrophobic surfactants and contact-regulated production. Environ Microbiol. 2011;13:2681-91.

17. Yoon JH, Kim IG, Kang KH, Oh TK, Park YH. Bacillus hwajinpoensis sp. nov. and an unnamed Bacillus genomospecies, novel members of Bacillus rRNA group 6 isolated from sea water of the East Sea and the Yellow Sea in Korea. Int J Syst Evol Microbiol. 2004;54:803-8.

18. Liu C, Wu Y, Li L, Ma Y, Shao Z. Thalassospira xiamenensis sp. nov. and Thalassospira profundimaris sp. nov. Int J Syst Evol Microbiol. 2007;57:316-20.

19. Zhao B, Wang H, Li R, Mao X. Thalassospira xianhensis sp. nov., a polycyclic aromatic hydrocarbon-degrading marine bacterium. Int I Syst Evol Microbiol. 2010;60:1125-9.

20. Sánchez-Porro C, Kaur B, Mann H, Ventosa A. Halomonas titanicae sp. nov., a halophilic bacterium isolated from the RMS titanic. Int J Syst Evol Microbiol. 2010;60:2768-74.

21. Poli A, Esposito E, Orlando P, Lama L, Giordano A, de Appolonia F, Nicolaus B, Gambacorta A. Halomonas alkaliantarctica sp. nov., isolated from saline lake Cape Russell in Antarctica, an alkalophilic moderately halophilic, exopolysaccharide-producing bacterium. Syst Appl Microbiol. 2007:30(1):31-8.

22. Arahal DR, Ludwig W, Schleifer KH, Ventosa A. Phylogeny of the family Halomonadaceae based on $23 \mathrm{~S}$ and $16 \mathrm{~S}$ rDNA sequence analyses. Int J Syst Evol Microbiol. 2002;52:241-9.

23. Gärdes A, Kaeppel E, Shehzad A, Seebah S, Teeling H, Yarza P, Glöckner FO, Grossart HP, Ullrich MS. Complete genome sequence of Marinobacter adhaerens type strain (HP15), a diatom-interacting marine microorganism. Stand Genomic Sci. 2010;3:97-107.

24. Green DH, Bowman JP, Smith EA, Gutierrez T, Bolch CJ. Marinobacter algicola sp. nov., isolated from laboratory cultures of paralytic shellfish toxin-producing dinoflagellates. Int J Syst Evol Microbiol. 2006;56:523-7.

25. Ng HJ, López-Pérez M, Webb HK, Gomez D, Sawabe T, Ryan J, Vyssotski M, Bizet C, Malherbe F, Mikhailov VV, Crawford RJ, Ivanova EP. Marinobacter salarius sp. nov. and Marinobacter similis sp. nov., isolated from sea water. PLoS ONE. 2014;9:e106514.

26. Lai Q, Liu Y, Yuan J, Du J, Wang L, Sun F, Shao Z. Multilocus sequence analysis for assessment of phylogenetic diversity and biogeography in
Thalassospira bacteria from diverse marine environments. PLOS ONE. 2014;9:e106353.

27. de la Haba RR, Arahal DR, Márquez MC, Ventosa A. Phylogenetic relationships within the family Halomonadaceae based on comparative $23 \mathrm{~S}$ and $16 \mathrm{~S}$ rRNA gene sequence analysis. Int J Syst Evol Microbiol. 2010;60:737-48.

28. Jiang Z, Zhang DF, Khieu TN, Son CK, Zhang XM, Cheng J, Tian XP, Zhang $\mathrm{S}$, Li WJ. Bacillus tianshenii sp. nov., isolated from a marine sediment sample. Int J Syst Evol Microbiol. 2014;64:1998-2002.

29. Bonin P, Vieira C, Grimaud R, Militon C, Cuny P, Lima O, Guasco S, Brussaard CP, Michotey V. Substrates specialization in lipid compounds and hydrocarbons of Marinobacter genus. Environ Sci Pollut Res Int. 2015;22:15347-59.

30. Harrison JP, Hallsworth JE, Cockell CS. Reduction of the temperature sensitivity of Halomonas hydrothermalis by iron starvation combined with microaerobic conditions. Appl Environ Microbiol. 2015;81:2156-62.

31. Cai Q, Zhang B, Chen B, Zhu Z, Lin W, Cao T. Screening of biosurfactant producers from petroleum hydrocarbon contaminated sources in cold marine environments. Mar Pollut Bull. 2014;86:402-10.

32. Gutiérrez T, Mulloy B, Bavington C, Black K, Green DH. Partial purification and chemical characterization of a glycoprotein (putative hydrocolloid) emulsifier produced by a marine bacterium Antarctobacter. Appl Microbiol Biotechnol. 2007;76:1017-26.

33. Gutiérrez T, Mulloy B, Black K, Green DH. Glycoprotein emulsifiers from two marine Halomonas species: chemical and physical characterization. J Appl Microbiol. 2007;103:1716-27.

34. Das P, Mukherjee S, Sen R. Antimicrobial potential of a lipopeptide biosurfactant derived from a marine Bacillus circulans. J Appl Microbiol. 2008;104:1675-84

35. Liu Z, Liu J. Evaluating bacterial community structures in oil collected from the sea surface and sediment in the northern Gulf of Mexico after the Deepwater Horizon oil spill. MicrobiologyOpen. 2013;2:492-504.

36. Cui Z, Lai Q, Dong C, Shao Z. Biodiversity of polycyclic aromatic hydrocarbon-degrading bacteria from deep sea sediments of the Middle Atlantic Ridge. Environ Microbiol. 2008;10:2138-49.

37. Jiménez N, Viñas M, Guiu-Aragonés C, Bayona JM, Albaigés J, Solanas AM. Polyphasic approach for assessing changes in an autochthonous marine bacterial community in the presence of Prestige fuel oil and its biodegradation potential. Appl Microbiol Biotechnol. 2011;91:823-34.

38. Gudiña EJ, Pereira JF, Costa R, Evtuguin DV, Coutinho JA, Teixeira JA, Rodrigues LR. Novel bioemulsifier produced by a Paenibacillus strain isolated from crude oil. Microb Cell Fact. 2015;14:14-24.

39. Dubey KV, Charde PN, Meshram SU, Shendre LP, Dubey VS, Juwarkar AA. Surface-active potential of biosurfactants produced in curd whey by Pseudomonas aeruginosa strain-PP2 and Kocuria turfanesis strain-J at extreme environmental conditions. Bioresour Technol. 2012;126:368-74.

40. White DA, Hird LC, Ali ST. Production and characterization of a trehalolipid biosurfactant produced by the novel marine bacterium Rhodococcus sp. strain PML026. J Appl Microbiol. 2013;115:744-55.

41. Vilela WF, Fonseca SG, Fantinatti-Garboggini F, Oliveira VM, Nitschke M. Production and properties of a surface-active lipopeptide produced by a new marine Brevibacterium luteolum strain. Appl Biochem Biotechnol. 2014;174:2245-56.

42. Beltrani T, Chiavarini S, Cicero DO, Grimaldi M, Ruggeri C, Tamburini E, Cremisini C. Chemical characterization and surface properties of a new bioemulsifier produced by Pedobacter sp. strain MCC-Z. Int J Biol Macromol. 2015;72:1090-6.

43. Kong J, Yu S. Fourier transform infrared spectroscopic analysis of protein secondary structures. Acta Biochim Biophys Sin. 2007;39:549-59.

44. Adochitei A, Drochioiu G. Rapid Characterization of peptide secondary structure by FT-IR spectroscopy. Rev Roum Chim. 2011;56:783-91.

45. Fernandez C, Ausar SF, Badini RG, Castagna LF, Bianco ID, Beltramo DM. An FTIR spectroscopy study of the interaction between a-casein-bound phosphoryl groups and chitosan. Int Dairy J. 2003;13:897-901.

46. de Sousa T, Bhosle S. Isolation and characterization of a lipopeptide bioemulsifier produced by Pseudomonas nitroreducens TSB.MJ10 isolated from a mangrove ecosystem. Bioresour Technol. 2012;123:256-62.

47. Walzer G, Rosenberg E, Ron EZ. Identification of outer membrane proteins with emulsifying activity by prediction of beta-barrel regions. J Microbiol Methods. 2009;76:52-7. 
48. GutierrezT, Morris G, Green DH. Yield and physicochemical properties of EPS from Halomonas sp. strain TG39 identifies a role for protein and anionic residues (sulfate and phosphate) in emulsification of $\mathrm{n}$-hexadecane. Biotechnol Bioeng. 2009;103:207-16.

49. Manivasagan P, Sivasankar P, Venkatesan J, Sivakumar K, Kim SK. Optimization, production and characterization of glycolipid biosurfactant from the marine actinobacterium, Streptomyces sp. MAB36. Bioprocess Biosyst Eng. 2014;37:783-97.

50. Dhasayan A, Kiran GS, Selvin J. Production and characterisation of glycolipid biosurfactant by Halomonas sp. MB-30 for potential application in enhanced oil recovery. Appl Biochem Biotechnol. 2014;174:2571-84.
51. Franzetti A, Gandolfi I, Raimondi C, Bestetti G, Banat IM, Smyth TJ, Papacchini M, Cavallo M, Fracchia L. Environmental fate, toxicity, characteristics and potential applications of novel bioemulsifiers produced by Variovoraxparadoxus 7bCT5. Bioresour Technol. 2012;108:245-51.

52. Sriram MI, Gayathiri S, Gnanaselvi U, Jenifer PS, Mohan Raj S, Gurunathan S. Novel lipopeptide biosurfactant produced by hydrocarbon degrading and heavy metal tolerant bacterium Escherichia fergusonii KLU01 as a potential tool for bioremediation. Bioresour Technol. 2011;102:9291-5.

\section{Submit your next manuscript to BioMed Central and we will help you at every step:}

- We accept pre-submission inquiries

- Our selector tool helps you to find the most relevant journal

- We provide round the clock customer support

- Convenient online submission

- Thorough peer review

- Inclusion in PubMed and all major indexing services

- Maximum visibility for your research

Submit your manuscript at www.biomedcentral com/submit 